\title{
Destigmatizing Disability in the Law of Immigration Admissions
}

Medha D. Makhlouf

Penn State Dickinson Law, mdm5849@psu.edu

Follow this and additional works at: https://ideas.dickinsonlaw.psu.edu/fac-books

Part of the Disability Studies Commons, Health Law and Policy Commons, Health Policy Commons, Immigration Law Commons, Inequality and Stratification Commons, Law and Society Commons, Social Policy Commons, Social Welfare Commons, and the Social Welfare Law Commons

\section{Recommended Citation}

Makhlouf, Medha D., "Destigmatizing Disability in the Law of Immigration Admissions" (2020). Faculty Books. 1.

https://ideas.dickinsonlaw.psu.edu/fac-books/1

This Book Chapter is brought to you for free and open access by the Faculty Scholarship at Dickinson Law IDEAS. It has been accepted for inclusion in Faculty Books by an authorized administrator of Dickinson Law IDEAS. For more information, please contact lja10@psu.edu. 


\title{
Disability, Health, Law, and Bioethics
}

\author{
Edited by \\ I. GLENN COHEN \\ Harvard Law School \\ CARMEL SHACHAR \\ Harvard Law School \\ ANITA SILVERS \\ San Francisco State University \\ MICHAEL ASHLEY STEIN \\ Harvard Law School
}




\section{CAMBRIDGE UNIVERSITY PRESS}

University Printing House, Cambridge св2 8в s, United Kingdom

One Liberty Plaza, 2oth Floor, New York, NY 10006, USA

477 Williamstown Road, Port Melbourne, vIC 3207, Australia

314-321, 3rd Floor, Plot 3, Splendor Forum, Jasola District Centre, New Delhi - 110025, India

79 Anson Road, \#०6-04/o6, Singapore 079906

Cambridge University Press is part of the University of Cambridge.

It furthers the University's mission by disseminating knowledge in the pursuit of

education, learning, and research at the highest international levels of excellence.

www.cambridge.org

Information on this title: www.cambridge.org/9781108485975

DOI: $10.1017 / 9781108622851$

(C) Cambridge University Press 2020

This publication is in copyright. Subject to statutory exception and to the provisions of relevant collective licensing agreements, no reproduction of any part may take place without the written permission of Cambridge University Press.

First published 2020

A catalogue record for this publication is available from the British Library.

Library of Congress Cataloging-in-Publication Data

names: Cohen, I. Glenn, editor. | Shachar, Carmel, 1985- editor. | Silvers, Anita, editor. | Stein, Michael Ashley, editor.

TITLE: Disability, health, law, \& bioethics / edited by I. Glenn Cohen, Carmel Shachar, Anita Silvers, Michael Ashley Stein.

OTHER TITLES: Disability, health, law, and bioethics

Description: Cambridge ; New York, NY : Cambridge University Press, 2020. | Includes bibliographical references.

IDENTIFIERS: LCCN 2019039765 (print) | LCCN 2019039766 (ebook) | ISBN 9781108485975 (hardback) | ISBN 9781108725408 (paperback) | ISBN 9781108622851 (ebook)

subjects: mesh: Disabled Persons - psychology | Bioethical Issues | Disabled Persons legislation \& jurisprudence | Health Services for Persons with Disabilities | Social Stigma CLASSIFICATION: LCC HV1568 (print) | LCC HV1568 (ebook) | NLM HV 1568 | DDC 362.4-dc23

LC record available at https://ccn.loc.gov/2019039765

LC ebook record available at https://lccn.loc.gov/2019039766

ISBN 978-1-108-48597-5 Hardback

ISBN 978-1-108-72540-8 Paperback

Cambridge University Press has no responsibility for the persistence or accuracy of URLs for external or third-party internet websites referred to in this publication and does not guarantee that any content on such websites is, or will remain, accurate or appropriate. 


\section{Contents}

Notes on Contributors

page xii

Introduction

XV

Carmel Shachar, I. Glenn Cohen, and Michael Ashley Stein

Preface

xxix

Tom Shakespeare

Acknowledgments

xxxii

PART I DISABILITY: DEFINITIONS AND THEORIES

Introduction

I. Glenn Cohen

1 Disability, Health, and Normal Function

Elizabeth Barnes

$2 \quad$ Healthcare As Eugenics

Ani B. Satz

3 Epistemic Injustice, Disability Stigma, and Public Health Law

Daniel Goldberg

PART II DISABILITY IN THE BEGINNING AND THE END OF LIFE

Introduction

I. Glenn Cohen

4 Abortion, the Disabilities of Pregnancy, and the Dignity of Risk

Mary Anne Case 
5 The Down Syndrome Information Act and "Mere Difference":

Redefining the Scope of Prenatal Testing Conversations?

Marie-Eve Lemoine and Vardit Ravitsky

6 Dementia, Disability, and Advance Medical Directives: Defensible Standards for Dementia Care

Rebecca Dresser

PART III DISABILITY IN THE CLINICAL SETTING

Introduction

Carmel Shachar

7 Expressing Respect for People with Disabilities in Medical Practice

Adam Cureton

8 Disabled Bodies and Good Organs

Emily A. Largent

9 Humanizing Clinical Care for Patients with Disabilities

Omar Sultan Haque and Michael Ashley Stein

10 Chronic Pain As a Challenge for Disability Theory and Policy

Caroline J. Huang and David Wasserman

PART IV EQUALITY, EXPERTISE, AND ACCESS

Introduction

Michael Ashley Stein

11 Making "Meaningful Access" Meaningful: Equitable Healthcare for Divisive Times

Leslie Francis and Anita Silvers

12 The Privacy Problem in Disability Antidiscrimination Law

Jasmine E. Harris

13 Sexual Agency As a Rights-Based Imperative for Persons with Intellectual Disabilities

Matthew S. Smith, Tara Allison, and Michael Ashley Stein 
14 Destigmatizing Disability in the Law of Immigration Admissions $\quad 187$ Medha D. Makhlouf

15 The Normative Bases of Medical Civil Rights

200

Craig Konnoth

16 Judicial Representation: Speaking for Others from the Bench

211

Wendy Salkin

PART VI QUANTIFYING DISABILITY

221

Introduction

223

William P. Alford

17 Can We Universally Accommodate Mental Health and Should We?

A Systematic Review of the Evidence and Ethical Analysis

Nathaniel Z. Counts, C. Taylor Poor, Julie Erickson, Thomas Hart, 227 and Kelly A. Davis

18 Algorithmic Disability Discrimination 242

Mason Marks

19 The Pathways Approach to Priority Setting: Considering Quality of Life While Being Fair to Individuals with Disabilities

Govind Persad

20 Measuring Health-State Utility via Cured Patients 


\title{
Destigmatizing Disability in the Law of Immigration Admissions
}

\author{
Medha D. Makhlouf
}

Ever since the federal government began comprehensively regulating immigration in the late nineteenth century, noncitizens with traits associated with disability have faced more legal barriers to immigration than noncitizens without disabilities. ${ }^{1}$ Federal laws excluding noncitizens on the basis of vague, health-related criteria have existed since $1882 .{ }^{2}$ In the early twentieth century, the US Public Health Service instructed medical inspectors to search for evidence of conditions such as bunions, flat feet, hernia, hysteria, poor eyesight, psychoses of various kinds, spinal curvature, and varicose veins. ${ }^{3}$ It is not an overstatement to say that the exclusion of people with disabilities was a pillar of early immigration policy. ${ }^{4}$

The motivations behind such laws at the turn of the century were clear: first, fear of disability itself was pervasive; and second, there were concerns about increasing hereditary disability within the population. The latter concern was in line with the ideology of eugenics, which profoundly influenced the evolution of early immigration restrictions. ${ }^{5}$ Labor policy characterizing noncitizens with disabilities as undesirable workers also supported disability-related immigration restrictions.

Although these laws have been relaxed over time, noncitizens with a variety of disabilities are still considered inadmissible on account of their health status. These disfavored disabilities include certain communicable diseases, physical or mental health disorders that may cause harmful behaviors, substance dependence or abuse disorder, and any other condition that prevents participation in the labor force and the ability to provide for oneself.

1 See Mark C. Weber, Opening the Golden Door: Disability and the Law of Immigration, 8 J. Gender Race \& Just. 153, 155 (2004).

2 Act of August 3, 1882, ch. 376, 22 Stat. 214, 214 (denying entry to "any convict, lunatic, idiot, or any person unable to take care of himself or herself without becoming a public charge").

3 U.S. Pub. Health Serv., Regulations Governing the Medical Inspection of Aliens 16-19 (1917), available at archive.org/details/regulationsgoveooservgoog.

4 See Douglas C. Baynton, Defectives in the Land: Disability and American Immigration Policy, 1882-1924, 24 J. Am. Ethnic Hist. 31, 34 (2005).

5 See, for example, id. at 32; Weber, supra note 1, at 157-6o. See generally John Higham, Strangers in the Land: Patterns of American Nativism, 1860-1925, at 149-57, 273-77 (2nd ed. 2002). 
One of the goals of Disability Legal Studies (DLS) is to challenge existing hierarchies that exclude or marginalize people with disabilities. ${ }^{6}$ DLS espouses the "social model of disability," which looks beyond medical criteria to view disability as "the result of socio-cultural dynamics that occur in interactions between society and people with disabilities." 7 While acknowledging that disability can limit a person's capacity to do things that most people take for granted, this position maintains that people with disabilities are "limited more by social attitudes and environmental barriers than by any inherent 'defect' or 'deficiency' within the person." ${ }^{8}$ An important purpose of adopting the social model of disability was to characterize disability in a way that enhances advocacy for social change.

Among those whose views of disability fall within the social model, there is a split in the characterization of disability as a "mere difference" from the norm versus a "bad difference." The mere difference position maintains that "disability is not, by itself, something bad, harmful, or suboptimal." On the other side is the view that having a disability always makes a person worse off than she would have been had she been nondisabled, even if society has done everything possible to accommodate her disability. Disability-related immigration exclusions are manifestations of a bad difference viewpoint because they portray people with disabilities as "undesirable" entrants who threaten citizens in various ways. ${ }^{10}$ Viewed least charitably, the exclusions reflect an opinion of "people with disabilities as useless, marginal, abnormal, [and] a burden on society." ${ }^{\prime \prime}$ Such harsh conclusions about the value of people with disabilities go far beyond the assessment that society will never be able to fully accommodate disability.

Of course, sovereign nations have the right to construct their citizenry, and that includes creating guidelines for the admission of noncitizens and status-based criteria for entitlements. ${ }^{12}$ We justify laws that exclude disabled noncitizens from entering or immigrating to this country by pointing to their noncitizen status, not their disablement. Some might argue that it is common sense to prefer a healthy and able-bodied citizenry to one that is ill or disabled. That "common sense," however, reveals a blanket judgment about the inferiority of noncitizens with disabilities relative to noncitizens without disabilities.

Fundamentally, immigration and citizenship laws reflect societal norms about the types of people who will benefit the community of citizens. ${ }^{13}$ Exclusion directed

6 See Arlene S. Kanter, The Law: What's Disability Studies Got to Do with it or an Introduction to Disability Legal Studies, 42 Colum. Hum. Rts. L. Rev. 403, 415 (2011).

7 Id. at 407 .

8 Id. at 409. See also Elizabeth Barnes, Valuing Disability, Causing Disability, 125 Ethics 88, 93 (2014).

9 Barnes, supra note 8, at 89. Proponents of this view do acknowledge that there are some features or aspects of disability that "involve the loss of intrinsic goods or basic capabilities." Id. at 9o.

10 See, for example, Baynton, supra note 4, at 32; Polly J. Price, Infecting the Body Politic: Observations on Health Security and the "Undesirable" Immigrant, 63 U. Kan. L. Rev. 917, 918 (2015).

11 Sagit Mor, Between Charity, Welfare, and Warfare: A Disability Legal Studies Analysis of Privilege and Neglect in Israeli Disability Policy, 18 Yale J.L. \& Human. 63, 69 (2006).

12 See, for example, Price, supra note 10, at 920.

13 See Kit Johnson, Theories of Immigration Law, 46 Ariz. St. L.J. 1211, 1249 (2014). 
toward noncitizens with disabilities is related to the exclusion of citizens with disabilities in that it reflects the value society places on people with disabilities more generally. These exclusionary laws reinforce cultural norms that brand people with disabilities as inferior. ${ }^{14}$ The barriers - physical and attitudinal - that disabled citizens face will never be adequately addressed if we continue to exclude disabled noncitizens in the hopes of having a disability-free citizenry, rather than "accommodat[ing] disability into our culture." 15 For this reason, those who care about the welfare of disabled people living in the United States should be concerned with challenging the cultural and legal norms that have resulted in the exclusion of noncitizens with disabilities.

This chapter provides an overview of immigration exclusions that impact the ability of noncitizens with disabilities to enter and immigrate to the United States. It then describes what the law of immigration admissions might look like if it were to treat disability as a mere difference rather than a bad difference. I propose that a mere difference view in the immigration context must do more than merely treat disability as a neutral factor; rather, it must recognize the value of a citizenry that includes people with disabilities.

\section{LEGAL FRAMEWORK OF DISABILITY-RELATED IMMIGRATION EXCLUSIONS}

In order to enter the United States, noncitizens must meet certain criteria that are determined by the classification through which they seek to enter. Even if a noncitizen meets the eligibility criteria, the federal government may exclude him from entry if any of the grounds of inadmissibility apply to him. An examination of whether a noncitizen seeking to enter on a visa is excludable under these grounds happens twice: first by a Department of State (DOS) consular officer during the visa application process, and second by a Department of Homeland Security (DHS) immigration official upon arrival at a port of entry. The grounds of inadmissibility also apply to noncitizens who are seeking lawful permanent resident status, even if they have lived in the United States for many years. Sometimes, admissibility becomes an issue for lawful permanent residents who are applying to become US citizens. If any ground of inadmissibility applied but was overlooked at the time the applicant became a lawful permanent resident, she may be denied citizenship and is subject to deportation.

The grounds of inadmissibility are grouped into ten categories, two of which I describe as "disability related." The health-related exclusions are based on public

14 Kevin Johnson makes a similar argument regarding racial minority groups that are marginalized in immigration law. Kevin Johnson, Race, the Immigration Laws, and Domestic Race Relations: A "Magic Mirror" into the Heart of Darkness, 73 Ind. L.J. 1111, 1153 (1998).

15 Barnes, supra note 8, at 112 (quoting Laura Hershey, From Poster Child to Protestor, Crip Commentary (1993), cripcommentary.com/frompost.html). 
health concerns and include a variety of communicable and noncommunicable conditions. The public charge exclusion guards against noncitizens who would become dependent on government assistance for any reason and is often applied to applicants with disabilities.

\section{A. History of Disability As a Barrier to Immigration}

The first comprehensive federal immigration law, passed in 1882, excluded any "lunatic, idiot, or any person unable to take care of himself or herself without becoming a public charge. ${ }^{" 16}$ In the terminology of the time, this meant that any person determined to be mentally ill or intellectually disabled was automatically excluded. It was assumed that people categorized as such would be unable to support themselves through work and would become a burden on taxpayers. The inclusion of the more general "public charge" provision with these categories is an indication of its longstanding link to the exclusion of noncitizens based on perceived health-related grounds. In practice, the provision applied to individuals with a broad range of disabilities, and medical inspectors had wide discretion to apply it as they saw fit. ${ }^{17}$ In 1891 , the exclusion broadened from applying to those who were "unable" to provide for themselves, to those who were "likely to become a public charge." ${ }^{18}$ In 1907, the law was amended again to require a medical certificate for those determined to be "mentally or physically defective, such mental or physical defect being of a nature which may affect the ability of such alien to earn a living." ${ }^{\prime 19}$ Essentially, this provision required disabled noncitizens to meet a higher standard than noncitizens without disabilities in order to avoid exclusion under the public charge ground.

Although the rationale for excluding noncitizens with disabilities in the immigration context seemed to be related to cost concerns, historians have maintained that these were secondary to uneasiness about introducing "degenerate breeding stock" into the populace. ${ }^{20}$ From 1903 to 1917 , as the eugenics movement gained influence, several additional categories of "mental defect" were added to the exclusion. ${ }^{21}$ Likewise, noncitizens with physical disabilities or simply an "abnormal appearance" were excluded without regard to their history of self-support. ${ }^{22}$

16 Act of August 3, 1882, Pub. L. No. 47-376, \& 2, 22 Stat. 214, 214.

17 Baynton, supra note 4, at 33; Mark C. Weber, Immigration and Disability in the United States and Canada, 322 Windsor Y.B. Access to Just., 22 (2015).

18 Baynton, supra note 4 , at 33 .

19 Id. (emphasis in original) (quoting 34 Stat. 898, 899 (1907) (emphasis added)).

20 Higham, supra note 5, at 151.

${ }^{21}$ Baynton, supra note 4, at 33-34 (citing 32 Stat. 1213 (1903); 34 Stat. 898 (1907); and U.S. Public Health Serv., supra note 3, at 25-26, 28-29, 30-31 (1917)).

22 See, for example, United States ex rel. Barlin v. Rodgers, 191 F. 970 (3d Cir. 1911); United States ex rel. Canfora v. Williams, 186 F. 354 (S.D.N.Y. 1911); Baynton, supra note 4, at 31, 36-39 (describing cases in which noncitizens with proven ability to support themselves were nevertheless denied admission on account of physical disabilities). 
From 1921 to 1965 , immigration admissions were primarily determined by a quota system based on national origin that favored citizens of western and northern European countries. ${ }^{23}$ Advocates for the quota system claimed that disproportionate numbers of immigrants from particular countries were mentally or physically defective. ${ }^{24}$ Reform of the immigration laws in 1965 abolished the quota system and replaced it with one in which the vast majority of newcomers immigrate on the basis of family ties with citizens and lawful permanent residents. During this time, the medical examination process for noncitizens continued to identify those who were disabled, and to place a higher burden on them to prove that they would not become a public charge. ${ }^{25}$ Over the last several decades, the number of noncitizens excluded on the basis of disability has decreased. ${ }^{26}$ This change has been explained in part by the aforementioned shift in immigration policy from the focus on fulfilling labor needs to reunifying family members. It can also be attributed to a shift in popular attitudes towards people with disabilities: less fear, stigma, and concerns stoked by eugenic ideology. ${ }^{27}$

More recently, the reduction in disability-based immigration exclusions stems from changes to immigration law. Many of the immigration restrictions that have the effect of excluding people with disabilities have relaxed. ${ }^{28}$ The first indication of this trend was a provision within the Immigration Reform and Control Act of 1986 that created a disability waiver of the public charge exclusion for a subclass of undocumented immigrants that became newly eligible to obtain legal status. ${ }^{29}$

In 1990, Congress made an effort to update the health-related grounds of inadmissibility so that they were in accord with modern medical knowledge and procedure. ${ }^{30}$ For example, the provision that imposed an additional burden on people with disabilities to prove that they would not become a public charge was removed. ${ }^{31}$ Finally, the provision that specifically excluded noncitizens with mental retardation, psychopathic personality, or insanity was replaced with a more general exclusion that applied to noncitizens with disabilities who may pose a threat to themselves or others. ${ }^{32}$

23 For a detailed discussion of the motivations behind the national origins quota system, see Johnson, supra note 15, at 1127-31.

24 Baynton, supra note 4, at 41 .

25 See, for example, 8 U.S.C. $\$ 1182(a)(7)$ (1970) (requiring a noncitizen identified as having a disability that may affect her ability to work to prove that she "would not have to earn a living").

26 John F. Stanton, Note, The Immigration Laws from a Disability Perspective: Where We Were, Where We Are, Where We Should Be, 10 Geo. Immigr. L.J. 441, 451 (1996).

27 Weber, supra note 1, at 161-62; Stanton, supra note 26, at 452 .

28 Weber, supra note 1 , at 161.

29 Immigration and Nationality Act $\$ 245 \mathrm{~A}(\mathrm{~d})(2)(\mathrm{B})(\mathrm{ii}), 8$ U.S.C. $\$ 1255 \mathrm{a}(\mathrm{d})(2)(\mathrm{B})(\mathrm{ii})(2012)$ (hereinafter INA).

30 136 Cong. Rec. H 13238 (daily ed. October 26, 1990) (Joint explanatory statement of the Committee of Conference) (stating that the amendments to the Immigration and Nationality Act "repealed several outmoded grounds for exclusion based on health").

${ }^{31}$ Immigration Act of 1990, Pub. L. No. 101-649, \& 601, 104 Stat. 4978, 5067 (1990).

32 INA $\$ 212(\mathrm{a})(\mathrm{I})(\mathrm{A})(\mathrm{iii})$. 
Despite the changed perspectives on people with disabilities, there is still political and popular support for immigration restrictions that operate as exclusions against them. In line with this view, during the recent immigration reform debates the White House favored proposals that increase the proportion of immigrants who enter the country through "merit-based" pathways as opposed to family-based pathways, proposing a points-based system for immigrant admissions. Although no points were deducted for having a disability in these proposals, points were awarded in several categories in which people with certain disabilities are less likely to excel without specialized services, supports, and protections. ${ }^{33}$

\section{B. The Health-Related Grounds of Inadmissibility}

A medical examination is a standard requirement for many categories of applicants for admission. ${ }^{34}$ As part of this examination, a physician must determine whether the applicant has a physical or mental health condition that may make her inadmissible under any of the grounds of inadmissibility. A "Class A" medical condition, as defined in regulations issued by the Department of Health and Human Services, is one which falls within the health-related grounds of inadmissibility, described below. ${ }^{35}$ A "Class B" medical condition is "a physical or mental health condition, disease, or disability serious in degree or permanent in nature" that may prevent the applicant from caring for herself, attending school, or working, or that may require substantial medical treatment or institutionalization. ${ }^{36}$

Public health concerns informed by medical knowledge are at the heart of the health-related grounds of inadmissibility today. ${ }^{37}$ There are four major categories of health-related grounds for inadmissibility. The first ground deems inadmissible noncitizens who have a "communicable disease of public health significance" 38 such as gonorrhea, infectious Hansen's disease, active tuberculosis, and infectious syphilis. ${ }^{39}$ The second ground applies to noncitizens who have a "physical or mental disorder and behavior associated with the disorder that may pose ... a threat to the property, safety, or welfare of the alien or others." ${ }^{\circ}$ The third ground makes any

33 Such categories include years of formal education, English language proficiency, extraordinary achievement, and highly compensated employment.

34 INA $\iint 212,232$.

3542 C.F.R. $\$ 34 \cdot 2(\mathrm{~d})$.

$3^{6} 42$ C.F.R. $\int 34.2($ e); Policy Manual, Vol. 8 - Admissibility, Pt. B - Health-Related Grounds of Inadmissibility, Ch. 2 - Medical Examination and Vaccination Record, USCIS (February 12, 2019), www.uscis.gov/policymanual/HTML/PolicyManual-Volume8-PartB-Chapterz.html.

37 Policy Manual, Vol. 8 - Admissibility, Pt. B - Health-Related Grounds of Inadmissibility, Ch. 1 Purpose and Background, USCIS (February 12, 2019), www.uscis.gov/policymanual/HTML/ PolicyManual-Volume8-PartB-Chapterı.html.

$3^{8} \quad$ INA $\$ 212(\mathrm{a})(\mathrm{i})(\mathrm{A})(\mathrm{i})$.

$39 \quad 42$ C.F.R. $\int 34.2(\mathrm{~b})$.

$4^{\circ}$ INA $\$ 212(\mathrm{a})(\mathrm{I})(\mathrm{A})(\mathrm{iii})(\mathrm{I})$. 
noncitizen who is a "drug abuser or addict" excludable. ${ }^{41}$ The fourth ground deems inadmissible noncitizens who cannot provide documentation of required immunizations. ${ }^{42}$ Any condition that would make a person inadmissible under one or more of the four health-related grounds of inadmissibility is considered a Class A medical condition. It is possible for applicants who are subject to some of these grounds to receive a waiver of inadmissibility when they can prove that their medical conditions do not pose a risk to public health. ${ }^{43}$

\section{The Public Charge Ground of Inadmissibility}

The federal government considers the likelihood of a noncitizen becoming a "public charge" before permitting that person to enter the United States or to become a lawful permanent resident. ${ }^{44} \mathrm{~A}$ "public charge" is currently defined as a person who is likely to become "primarily dependent on the government for subsistence, as demonstrated by either (i) the receipt of public cash assistance for income maintenance, or (ii) institutionalization for long-term care at government expense." 45 Past receipt or the likelihood of future receipt of benefits from the following programs are considered: Supplemental Security Income, cash assistance from the Temporary Assistance for Needy Families program, state or local cash assistance programs for income maintenance (often referred to as "general assistance"), and Medicaid for long-term care in a nursing home or mental health institution. ${ }^{46}$

Officials use a highly discretionary totality of the circumstances type of test in making a public charge determination. ${ }^{47}$ Information from the medical examination may be used to make this determination, with disability treated as a negative factor. ${ }^{4}$ Indeed, there does not appear to be any other purpose for identifying noncitizens with Class B medical conditions other than to exclude them under the public charge provision. ${ }^{49}$

$4^{1} \quad$ INA $\int 212(\mathrm{a})(\mathrm{1})(\mathrm{A})(\mathrm{iv})$.

$4^{2}$ INA $\int 212(\mathrm{a})(\mathrm{1})(\mathrm{A})(\mathrm{ii})$.

43 Policy Manual, Vol. 9 - Waivers, Part C - Waivers for Health-Related Grounds of Inadmissibility, USCIS (February 12, 2019), www.uscis.gov/policymanual/Print/PolicyManual-Volumeg-PartC.html.

44 INA $\int 212(\mathrm{a})(4)$. But note that this ground of inadmissibility does not apply to certain categories of humanitarian immigrants.

45 Field Guidance on Deportability and Inadmissibility on Public Charge Grounds, 64 Fed. Reg. 28689, 28689 (March 26, 1999); 9 FAM 302.8-2(B)(1)(a)(1), Dep't of State (2018).

46 Field Guidance on Deportability and Inadmissibility on Public Charge Grounds, 64 Fed. Reg. at 28692; 9 FAM 302.8-2(B)(1)(b)-(d).

47 Weber, supra note 17 , at 26.

$4^{8}$ Policy Manual, Vol. 8 - Admissibility, Pt. B - Health-Related Grounds of Inadmissibility, Ch. 11 Inadmissibility Determination, USCIS (February 12, 2019), www.uscis.gov/policymanual/HTML/ PolicyManual-Volume8-PartB-Chapterı.html.

49 Stanton, supra note 26 , at 454 . 
For most family-based and certain employment-based immigrants, failure to submit an "affidavit of support" from a US-based sponsor will result in a denial of admission under the public charge ground. ${ }^{5 \circ}$ In the affidavit of support, the sponsor promises to support the applicant at an annual income of at least $125 \%$ of the federal poverty guidelines or reimburse the government if the applicant receives certain public benefits. ${ }^{51}$ Prior to January 2018, DOS guidance stated that "a properly filed, nonfraudulent [affidavit of support] shall normally be considered sufficient to overcome the [public charge] requirements." ${ }^{22}$ That guidance was changed so that an affidavit of support no longer satisfies the public charge requirements, but merely provides "additional evidence in the review of public charge determination" of visa applicants from abroad. ${ }^{53}$

This change to public charge policy was just one among many that were made or proposed by the current administration. In August 2019, DHS announced a final rule that could dramatically increase the number of applicants for admission and for adjustment of status who would be excluded under the public charge ground. Notably, the rule changes the definition of public charge to mean "an alien who receives one or more designated public benefits" over a certain period, and expands the types of public benefits that are considered in the determination..$^{54}$ Of particular concern for people with disabilities, receipt of nonemergency Medicaid by nonpregnant adults would be considered. ${ }^{55}$ The rule provides more specific guidelines on characteristics that should be considered negative factors in the public charge determination, specifying that health conditions that require extensive treatment or that affect an applicant's ability to work, attend school, or care for themselves are "heavily weighted negative factor[s]." ${ }^{6}$ As of the date of publication of this volume, two federal judges have issued nationwide injunctions temporarily blocking implementation of the public charge rule.

\section{TREATING DISABILITY AS A NEUTRAL FACTOR}

The social model of disability holds that "a principal source of the bad effects of disability is society's treatment of disabled people, rather than disability itself." ${ }^{77}$ When society perceives disability as a bad difference from prevalent or valued norms and imposes adverse or punitive conditions on people with disabilities on account of

$5 \circ \quad$ INA $\int 212(\mathrm{a})(4)(\mathrm{C}),(\mathrm{D})$.

${ }^{51}$ INA $\int \mathbb{S} 212(\mathrm{a})(4)(\mathrm{B})(\mathrm{ii}), 213 \mathrm{~A}$.

52 Ira J. Kurzban, Immigration Law Sourcebook 74 (14th ed. 2014) (quoting internal DOS guidance).

539 FAM 302.8-2(B)(3)(b)(1)(a).

54 Inadmissibility on Public Charge Grounds, 84 Fed. Reg. 41292, 41297-41298 (August 14, 2019) (to be codified at 8 C.F.R. pts. 103, 212, 213, 214, 245, and 248).

55 Id. at 41297.

${ }^{6}$ Id. at 41445 (noting that such a health condition will not be considered a heavily weighed negative factor if the applicant has private health insurance or the financial resources to pay for treatment).

57 Barnes, supra note 8, at 93. 
this perception, disability becomes stigmatized..$^{8}$ As a strategy to destigmatize disability, some disability theorists and advocates have promoted a view of disability as a mere difference from the norm. From this perspective, "people with disabilities occupy a social status analogous to that of racial and ethnic minorities and women, are victimized by negative stereotypes of dependence and incompetence, and experience intentional and institutional discrimination that limits their ability to fully participate in society." 59 A strategy to destigmatize disability could be modeled on the civil rights laws and policies that protect racial minorities from discrimination. In the context of immigration admissions, this would mean seeking formal equality by demanding that disability be treated as a neutral factor.

\section{A. Analysis of the Health-Related Grounds}

It is challenging to conceive of a way in which the health-related grounds of inadmissibility could be reformed in order to destigmatize disability from a mere difference perspective. Consider the second health-related ground, which applies to noncitizens who have a "physical or mental disorder and behavior associated with the disorder that may pose ... a threat to the property, safety, or welfare of the alien or others." ${ }^{\text {"To }}$ This provision relies on the assumption that medical examiners can identify individuals with mental disorders who will engage in violent behavior in the future, which is not the case. ${ }^{61}$ It is also grossly overinclusive: the term "mental disorder" covers a wide range of health conditions, including those that are unlikely to result in harm to oneself or others. As a result, there is a great risk that this healthrelated exclusion will bar noncitizens who are considered normatively "undesirable" for other reasons.

A mere difference approach requires a more focused assessment of the threat that individual noncitizens pose to society, independent of their disabilities. In practice, reforms of this health-related ground of inadmissibility might include: (1) eliminating the language about "physical or mental disorder" from the statute, to ensure that it is not a primary factor in the determination of dangerousness; (2) reclassifying the ground under a category of inadmissibility other than health-related, such as the criminal or national security grounds; and (3) amending administrative materials to remove references to specific mental disorders that are associated with harmful behavior.

Although this would be a symbolic step toward destigmatizing disability from the perspective of DLS, it may not have much practical effect. Immigration officials

$5^{8}$ See Joan Susman, Disability, Stigma and Deviance, 38 Soc. Sci. Med. 15, 16 (1994).

59 Richard K. Scotch \& Kay Schriner, Disability as Human Variation: Implications for Policy, 549 Annals Am. Acad. Pol. \& Soc. Sci. 148, 149 (1997).

6o INA $\$ 212(\mathrm{a})(1)(\mathrm{A})(\mathrm{iii}), 8$ U.S.C. $\$ 1182(\mathrm{a})(1)(\mathrm{A})(\mathrm{ii})(2012)$.

61 See Jeremy W. Coid et al., Predicting Future Violence Among Individuals with Psychopathy, 203 Brit. J. Psychiatry 387 (2013). 
could still rely on disability diagnoses in decisions to exclude noncitizens who they believe may pose a threat of harmful behavior in the future. So long as medical examinations of noncitizens are conducted, information about disabilities will appear in immigration applications.

Another potential way to treat mental illnesses and intellectual disabilities as mere differences, while preserving the goal of excluding those who would engage in harmful behaviors, is to chip away at the overinclusiveness of the inadmissibility ground. One way to do this would be through procedural reforms that hold the government to a higher evidentiary standard when it deems a person inadmissible under this ground. Still, neither of these reforms comes close to achieving "the reimagination of the place of disability within society" that DLS promotes. ${ }^{62}$

\section{B. Analysis of the Public Charge Ground}

The inclusion of "health" among the factors in the public charge test is intended to deny admission to people whose health conditions would prevent them from becoming self-sufficient through work. Overall, people with disabilities are less welloff financially than people without disabilities. ${ }^{6} 3$ This is attributable, in part, to society's inadequate accommodation of disabilities in schools and workplaces. ${ }^{64}$ In addition, many (but not all) disabilities arise from health conditions that require time and money to treat. ${ }^{65}$ Finally, noncitizens with disabilities who grew up in countries with fewer protections for people with disabilities may have been actually or constructively denied access to educational and employment opportunities. It should be no surprise that, as a group, people with disabilities are disproportionately subject to the public charge ground of inadmissibility.

For all of these reasons, the very act of recording a disability in an immigration application file likely has the effect of characterizing it as a bad difference. Given the broad discretion that immigration officers have in making this determination, and the fact that their decisions are essentially unreviewable, there is a strong possibility that longstanding social norms linking disability with dependency creep into these judgments. ${ }^{66}$ If the public charge rule goes into effect, the new guidelines designating certain health conditions as heavily weighted negative factors will all but require immigration officers to treat disabilities as bad differences.

62 Kanter, supra note 6, at 410.

63 See Samuel R. Bagenstos, The Future of Disability Law, 114 Yale L.J. 1, 9 (2004) (describing the relationship between disability and poverty).

64 See id. at 23-41.

65 Weber, supra note 1 , at 173.

66 See Stanton, supra note 26 , at 456 . On the non-reviewability of consular decisions to deny visas, see INA \$S 104(a), 221(a), 8 U.S.C. $\iint 1104(a), 1201(a)$ (2012); Saavedra Bruno v. Albright, 197 F.3d 1153 (D. C. Cir. 1999); 22 C.F.R. \42.81. But see Kleindienst v. Mandel, 408 U.S. 753 (1972) (holding that courts may review the denial of visas that implicate the constitutional rights of US citizens for abuse of discretion). 
To treat disability as a mere difference or neutral factor in this context - analogous to sexuality, gender, race, and ethnicity - health should be eliminated as a factor in the public charge determination. This reform would address unfair discrimination in the public charge assessments of a subset of people with disabilities: those who are able to become self-sufficient through work. For example, with conditions like blindness and deafness, it is possible to distinguish between impairments and the related disabilities, which can be described as the "socially mediated effects of impairments." ${ }^{67}$ However, one can conceive of many health conditions for which it is difficult or impossible to separate the impairment from the disability. Having a health condition that falls within this category does make a person less likely to participate in the workplace for reasons other than employer discrimination, and therefore more likely to become a public charge.

Therefore, a reform of the public charge ground that merely eliminates health as a factor in the public charge determination process would not likely affect the public charge ground's disproportionate impact on noncitizens with disabilities. In order to have an effect, the reform must squarely acknowledge the fact that people with disabilities are indeed disproportionately likely to rely on public benefits, regardless of whether reasonable accommodations could theoretically ameliorate the disability.

\section{DISABILITY AS A FORM OF HUMAN VARIATION THAT JUSTIFIES SPECIAL TREATMENT}

In the previous Section, I described how treating disability as a neutral factor in immigration admissions would not likely have a significant effect on the inadmissibility of people with disabilities. In this Section, I propose an alternative mere difference approach that frames disability as a form of human variation while acknowledging disability's inherent costs and our shared human vulnerability to these costs. Such an account of disability would support efforts to destigmatize disability in immigration law and to promote a more just societal allocation of the economic costs of disability. It does this by (1) characterizing immigrants with disabilities as valuable members of society, and (2) emphasizing collective responsibility for carrying the costs of disability.

The civil rights approach to combatting discrimination on the basis of race, ethnicity, and gender addresses the source of disadvantage for members of those groups: stereotypes of dependence and incompetence that cause them to be undervalued as scholars in the context of education, employees in the context of the workplace, and "productive" coresidents or citizens in the context of immigration admissions. However, this approach does not work as well to advance equality for people with disabilities. This is because the fundamental source of disadvantage for

67 Barnes, supra note 8 , at 89 n.1. 
people with disabilities in immigration admissions is not unfair discrimination; it is the inherent and inevitable costs of disability. Characterizing disability as a neutral factor for immigration admissions purposes fails to acknowledge these costs.

A model of disability that acknowledges these costs does not require one to view disability as a bad difference, so long as one recognizes that "something can be neutral overall, but have aspects which are bad." ${ }^{\prime 6}$ Likewise, by contemplating the nonstandard ways in which immigrants with disabilities contribute to the polity, a mere difference view can acknowledge the ways in which society is better off because of its inclusivity. ${ }^{69}$ Although a thorough exploration of the instrumental value of promoting human diversity in US society through immigration policy is beyond the scope of this chapter, I posit that any reform of the disability-related grounds must be built on the understanding that disablement is a category of human vulnerability that is common and - for many - inevitable. This approach would require US citizens to confront directly the fact that the application of even neutralized disability-related grounds to noncitizens with disabilities results in the territorial exclusion of a group of people who constitute a substantial minority of any given population. Finally, since potential for economic productivity is one standard by which immigrants seeking admission are judged, this approach would raise the question of the government's moral responsibility for maximizing each immigrant's productivity.

Currently, disability-related costs are borne solely by noncitizens seeking admission, their immediate family members, and their sponsors. For noncitizens with disabilities who manage to gain admission to the United States, as well as those who become disabled after admission, the health-related financial burden of disability is heavy. Noncitizen eligibility for publicly financed healthcare and other health-supporting benefits is limited. Without affordable access to healthcare, people with disabilities are vulnerable to falling into a cycle of health complications, decreased employment prospects, and poverty. Therefore, reform of the disability-related grounds of inadmissibility will not be complete without a fundamental societal shift toward embracing collective responsibility for maximizing the welfare of people with disabilities, which means willingly assuming the costs of their disabilities. An approach that frames disability as human variation supports reforms that guarantee more than formal equality for people with disabilities; it pushes for something closer to functional equality, which would require fundamentally different treatment for people with disabilities in immigration admissions.

68 Elizabeth Barnes, The Minority Body: A Theory of Disability 75-76 (2016).

69 See, for example, Angela Glover Blackwell, The Curb-Cut Effect, Winter 2017 Stan. Soc. Innovation Rev. 28 (2017). 


\section{CONCLUSION}

In US immigration law, disability has historically been associated with deviance and has served as the basis for legal barriers to entry and eventual citizenship. Although the law has evolved to accommodate immigrants with disabilities in some ways, significant legal barriers still exist on account of the widespread, persistent characterization of disability as a bad difference from the norm.

One potential strategy to treat disability as a mere difference in the law of immigration admissions is modeled on the civil rights approach, which supports reforms that would treat disability as a neutral factor in admissions decisions. Although such a strategy would likely result in the admission of a subset of disabled noncitizens who would otherwise be denied, it would be ineffective at destigmatizing disabilities that are difficult or impossible to accommodate, and that have inherent costs.

I propose an alternative strategy based on the mere difference view: frame disability as a form of human variation, while acknowledging disability's inherent costs and our shared human vulnerability to those costs. This perspective represents a promising first step toward supporting both a destigmatizing account of disablement in immigration admissions and a more just societal allocation of the economic costs of disability. 